\title{
STUDI KOMPONEN KIMIA PELEPAH SAWIT VARIETAS TENERA DAN PENGEMBANGANNYA SEBAGAI MODUL PEMBELAJARAN KIMIA
}

\section{(Study of Chemical Components of Pelepah Sawit the Variety of Tenera and the Development as a Chemical Learning Module)}

\author{
Arpinaini $^{1 *}$, Sumpono ${ }^{2}$, Ridwan Yahya ${ }^{2}$ \\ ${ }^{1}$ Mahasiswa Pascasarjana Pendidikan IPA, Universitas Bengkulu, 38371 \\ ${ }^{2}$ Dosen Pascasarjana Pendidikan IPA, Universitas Bengkulu, 38371 \\ *Email : arpinaini80@gmail.com
}

\begin{abstract}
This study aims to (1) determine the levels of the components of the Tenera variety of palm oil compounds including extractives, holocellulose, $\alpha$ - cellulose, and lignin. (2) Analyze the utilization of the pulp of Tenera varieties as pulp raw materials based on their chemical components; (3) application of chemistry learning module to improving student learning outcomes. Determination of extractive substance content with TAPPI test methods Q: 204; lignin content T: 222; holocellulose Q: 9 levels and $\alpha$-cellulose content with TAPPI test methods T: 204. then lignin, holocellulose and a-cellulose produced from the procedure were characterized by an IR spectrophotometer. The results of the study were module and implemented in ICHO students in SMAN 2 Kota Bengkulu. The data of the research results were analyzed by ANOVA test at $5 \%$ level. The results of the characterization of lignin, holocellulose and a-cellulose with FTIR obtained a distinctive peak of the respective functional groups of the macromolecules. From the research also obtained the average value of chemical component content on the palm velvet varieties of tenera according to their part of base, middle, ends with mean for extractive substance $8.49 \%, 7,87 \%, 6,74 \%$, lignin 20,7 $\%, 18.95 \%, 16.69 \%$. holocellulose $81.57 \%, 80.33 \%, 79.24 \%$ and $\alpha$ - cellulose $44.57 \%$, $43.56 \%, 43.26 \%$. Based on the results of the variance analysis, the difference in position (base, center, tip) on the palm oil of the tenera varieties on extractive, lignin, holocellulose and $\alpha$-cellulose substances has significant differences. Based on the chemical component classification of Indonesian wide wood leaf, sheep betera varieties of tenera in all three positions are used as pulp raw materials because they have moderate lignin content, high levels of Holocellulose and moderate levels of a-cellulose. The result of module implementation in students there is a significant difference between pretest and posttest value. The use of modules in learning in science groups can improve student learning outcomes.
\end{abstract}

Keywords: Density, Chemical component, Varietal Varietal of Tenera, module

\begin{abstract}
ABSTRAK
Penelitian ini bertujuan untuk (1) menentukan kadar komponen kimia pelepah sawit varietas Tenera yang meliputi zat ekstraktif, holoselulosa, $\alpha$ - selulosa, dan lignin (2)Menganalisis pemanfaatan pelepah sawit varietas Tenera sebagai bahan baku pulp berdasarkan komponen kimianya, (3) Mengetahui pengaruh penerapan modul pembelajaran kimia terhadap peningkatan hasil belajar siswa.Penentuan kadar zat ekstraktif dengan TAPPI test methods T:204; kadar lignin T:222 ; kadar holoselulosa T:9 dan kadar $\alpha$-selulosa dengan TAPPI tes methods T:204. kemudian lignin, holoselulosa dan a-selulosa yang dihasilkan dari prosedur tersebut dikarakterisasi dengan Spektrofotometer IR. Hasil penelitian dibuat modul dan diimplementasikan pada siswa ICHO di SMAN 2 Kota Bengkulu. Data hasil penelitian di analisis dengan uji ANOVA pada taraf $5 \%$. Hasil penelitian dari karakterisasi lignin, holoselulosa dan a-selulosa dengan FTIR diperoleh puncak yang khas dari gugus
\end{abstract}


fungsi penyusun masing-masing makromolekul tersebut. Dari penelitian juga diperoleh nilai rerata kadar komponen kimia pada pelepah sawit varietas tenera menurut bagiannya dari pangkal, tengah, ujung berturut-turut dengan rerata untuk kadar zat ekstraktif $8,49 \%, 7,87 \%$, $6,74 \%$, lignin 20,7\%, 18,95\%, 16,69\%. holoselulosa 81,57\%, 80,33\%, 79,24\% dan $\alpha-$ selulosa 44,57 \%, 43,56\%, 43,26\%. Berdasarkan hasil analisis variannya, perbedaan posisi (pangkal, tengah, ujung) pada pelepah sawit varietas tenera pada zat ekstraktif, lignin, holoselulosa dan $\alpha$ - selulosa memiliki perbedaan yang nyata. Berdasarkan klasifikasi komponen kimia kayu daun lebar indonesia, pelepah sawit varietas tenera pada ketiga posisinya baik dijadikan sebagai bahan baku pulp karena memiliki kadar lignin yang sedang, kadar Holoselulosa yang tinggi dan kadar $\alpha$ - selulosa yang sedang. Hasil implementasi modul pada siswa terdapat perbedaan yang signifikan antara nilai pretest dan posttest. Penggunaan modul dalam pembelajaran pada kelompok sains dapat meningkatkan hasil belajar siswa.

Kata kunci: Kerapatan, komponen Kimia, Pelepah sawit Varietas Tenera, modul

\section{PENDAHULUAN}

Perkembangan industri pulp dan kertas sekarang mengalami kemajuan yang sangat pesat khususnya di Indonesia. Hal ini disebabkan semakin meningkatnya kebutuhan manusia akan pulp dan kertas. Kurun waktu tahun 2004 - 2008, kapasitas produksi pulp nasional mengalami peningkatan rata-rata $0,6 \%$ per tahun, yaitu 2,5 juta ton per tahun menjadi 6,4 juta ton per tahun. Sedangkan, konsumsi kertas dunia naik 2,5-3\% per tahun (Cahya, 2011).

Kekurangan bahan baku pulp dan kertas dari bahan kayu memaksa pihak industri harus mencari alternatif bahan baku yang lain, misalnya bahan baku bukan kayu dan limbah. Penggunaan limbah sebagai bahan baku pulp dan kertas akan memberikan dampak yang positif yaitu memberikan penghasilan tambahan bagi penghasil limbah serta dapat mengurangi dampak pencemaran dari limbah tersebut. Syarat limbah yang dapat dijadikan bahan baku pulp dan kertas yaitu mengandung lignoselulosa.

Di Provinsi Bengkulu jenis sawit yang banyak ditanam para petani maupun perusahaan perkebunan adalah jenis sawit dari varietas Tenera. Hal ini karena varietas tersebut dapat tumbuh dengan baik di daerah dataran rendah seperti di Kabupaten Bengkulu Tengah, Bengkulu Utara, MukoMuko, Seluma dan Bengkulu Selatan. Selain itu varietas ini memiliki kelebihan daging buah yang tebal dan kulit cangkang yang tipis. Hasil dari perkebunan sawit tersebut baru dimanfaatkan daging buahnya untuk pembuatan Crude Palm Oil (CPO) dan cangkangnya sebagai sumber energi. Sangat terbuka peluang untuk memanfaatkan limbah pelepahnya.

Pelepah kelapa sawit merupakan limbah yang dihasilkan dari tanaman kelapa sawit mulai dari pra panen hingga proses pemanenan. Limbah pelepah kelapa sawit dihasilkan dari proses pruning kelapa sawit di mana untuk satu pohon kelapa sawit dapat dihasilkan 22 - 26 pelepah setiap tahunnya (Ambarita dkk. 2015), Zulfansyah dkk (2011) menambahkan bahwa 1 ha kebun sawit diperkirakan menghasilkan $\pm 10,5$ ton pelepah pertahun. Limbah pelepah kelapa sawit hasil pruning biasanya dibuang begitu saja atau dibiarkan membusuk di bawah pohon kelapa sawit (Ambarita, dkk. 2015). Pemanfaatan limbah pelepah kelapa sawit mulai dikembangkan misalnya sebagai pakan ternak dan pupuk kompos, namun ditinjau dari komposisi kimianya limbah pelepah kelapa sawit mempunyai potensi yang cukup besar untuk diolah lebih lanjut menjadi produk yang bermanfaat dan lebih bernilai ekonomis, salah satunya dengan memanfaatkan limbah pelepah kelapa sawit sebagai bahan baku industri pulp

Analisa kimia yang dilakukan Wardani (2015) menunjukkan bahwa pelepah sawit mengandung komponen selulosa, hemiselulosa, dan lignin. Lebih lanjut dalam penelitian tersebut Wardani melaporkan bahwa Kandungan lignin pelepah sawit 
bagian pangkal lebih tinggi dan menurun pada bagian tengah dan ujung. Namun sayangnya di dalam penelitian tersebut tidak disebutkan secara jelas varietas yang diteliti. Yahya (2013) melaporkan bahwa ditemukan perbedaan komponen antara tandan kosong kelapa sawit varietas dura dan tenera dimana kadar holoselulosa varietas tenera secara signifikan lebih tinggi daripada varietas dura. Berdasarkan hal ini dan fenomena bahwa tenera mendominasi varietas kelapa sawit yang ditanam di Provinsi Bengkulu sebagaimana uraian diatas, maka dianggap perlu untuk meneliti komponen kimia pelepah sawit varietas tenera bagian pangkal, tengah dan ujungnya.

Selama ini, penyampaian materi ajar tentang makromolekul yang merupakan materi lanjut pada kelompok sains kimia yaitu International Olympiade Chemistry organization (ICHO) di SMAN 2 Kota Bengkulu hanya disampaikan secara umum tanpa menggunakan media ajar karena keterbatasan sarana dan prasarana, media pembelajaran karena pelaksanaan pembelajarannya dilakukan pada sore hari. Guru hanya mengajarkan dengan metode ceramah, sehingga perlu adanya perbaikan dalam kegiatan pembelajaran dengan menggunakan bantuan media, sehingga dapat meningkatkan pemahaman konsep, hasil belajar, dan keaktifan peserta didik, .

Dalam penelitian pembelajaran ini menggunakan sumber belajar berupa modul. Setiap modul harus memberikan informasi dan petunjuk pelaksanaan yang jelas, Sehingga diharapkan dengan sumber belajar modul ini dapat mengarahkan pembelajaran menjadi lebih mudah, tepat dan mandiri. Modul merupakan salah satu bentuk bahan ajar yang dikemas secara utuh dan sistematis, didalamnya memuat seperangkat pengalaman belajar yang terencana dan didesain untuk membantu peserta didik menguasai tujuan belajar yang spesifik.

\section{METODE PENELITIAN}

\section{Alat dan Bahan}

Alat yang digunakan dalam penelitian ini adalah parang, pisau, alat pasa, grinder, gelas beaker, timbangan analitik, gelas erlenmeyer , termometer, gelas filter P.100(IG3), gelas filter P16(IG4), lemari asam, soklet, oven, saringan 40 mesh, lemari asam, volumetrik flash $10 \mathrm{~mL}$, pengaduk kaca, stirer, botol semprot, water bath, autoclave, botol kecil berpenutup, desikator, penjepit, vacum, batu pemanas dan thermolyne. kertas perkamen, kertas saring tipe 42, kertas tissue dan kertas label dan seperangkat alat FTIR. Sedangkan Bahan yang digunakan dalam penelitian eksperimen laboratorium adalah pelepah sawit varietas tenera, zat-zat kimia berupa natrium klorit $\left(\mathrm{NaClO}_{2}\right) 90,49 \%$, asam asetat $\left(\mathrm{CH}_{3} \mathrm{COOH}\right)$ $99,7 \%$ dan $5 \%$, aseton $\left(\mathrm{C}_{3} \mathrm{H}_{6} \mathrm{O}\right) \quad 99,5 \%$, Natrium Hidroksida $(\mathrm{NaOH}) \quad 17,5 \%$, etanol $\left(\mathrm{C}_{2} \mathrm{H}_{5} \mathrm{OH}\right) \quad 99,8 \%$, petroleum benzene dan Kalium Bikromat $\left(\mathrm{K}_{2} \mathrm{Cr}_{2} \mathrm{O}_{7}\right)$

\section{Rancangan Penelitian}

Penelitian ini menggunakan metode penelitian sampling, dengan teknik penentuan pohon kelapa sawit yang akan disampling yaitu terlebih dahulu dipilih pohon secara purposive dengan kriteria sehat, seumur, dan memiliki buah yang siap panen. Tiga pohon yang terpilih secara acak, kemudian diambil pelepahnya yang dijatuhkan oleh pendodos pada saat panen buah dilaksanakan.

Bagian pelepah yang diamati adalah bagian pangkal, tengah dan ujung. Dalam penelitian ini pohon sawit dianggap sebagai ulangan dengan jumlah masing-masing 3 pohon. Data hasil penelitian ini dianalisis dengan menggunakan analisis varian (ANOVA) yang mengikuti model rancangan acak lengkap (RAL) uji $\mathrm{F}$ dan taraf $5 \%$.

\section{Prosedur Kerja}

Penelitian penentuan komponen kimia pelepah sawit varietas tenera dilakukan di Laboratorium Kehutanan Divisi Teknologi Hasil Hutan Universitas Bengkulu dan karakterisasi seyawa lignin dan $\alpha$-selulosa dengan FTIR dilakukan di laboratorium kimia Institut Teknologi Bandung sedangkan penerapan pembelajaran dengan modul dilaksanakan di SMAN 2 Kota Bengkulu. Adapun secara garis besar prosedur kerja 
kegiatan analisis komponen kimia pelepah sawit varietas tenera adalah sebagai berikut:

1. Sampel Pelepah sawit varietas tenera yang diambil pada kebun milik warga di Desa Pondok Kelapa, Kabupaten Bengkulu Tengah. Kelapa sawit yang dijadikan Sampel berumur 7 - 8 tahun dengan berdiameter dan tinggi yang sama. Pelepah sawit yang dijadikan bahan penelitian adalah pelepah bagian pangkal, tengah dan ujung yang sudah dipisahkan dari daunnya.

2. Sampel pelepah sawit yang akan dianalisis komponen kimia dilaksanakan mengacu pada Tappi Test sampel pelepah sawit dipotong sebesar lidi korek api yang berukuran $\pm 10 \mathrm{~mm}$ dikeringkan kemudian digerinda menjadi serbuk berukuran 40 mesh. Pengujian komponen kimia untuk kadar ekstraktif larut dalam etanol toluene mengacu Tappi Test Methode T:204), Kadar Lignin mengacu pada Tappi Test Methods : T222, Kadar Holoselulosa mengacu pada Tappi Test Methods : T 9 dan kadar dan kadar a - Selulosa mengacu pada Tappi Test Methods : T 203

3. Dalam Penelitian penerapan modul dalam pembelalajaran menggunakan teknik tes dan non tes. Tes hasil belajar kimia yang dilakukan sebanyak dua kali yaitu pretest yang diberikan pada awal pembelajaran dan sesudah materi diajarkan (post test) menggunakan bahan ajar modul pembelajaran kimia sedangkan penilaian non tes menggunakan angket penilaian sikap dan angket respon siswa terhadap modul. Sebelum digunakan sebagai alat pengumpul data, tes telah diuji reliabilitas, taraf kesukaran dan daya beda.

\section{Analisa Data}

Data hasil penelitian disajikan dalam bentuk tabulasi rerata, grafik dan deskripsi. Untuk mengetahui pengaruh bagian pelepah sawit varietas Tenera terhadap nilai kerapatan dan komponen kimia, maka data dianalisis dengan menggunakan analisis varian (Anova) yang mengikuti model Rancangan Acak Lengkap
(RAL) uji $F$ pada taraf 5\%. Jika nilai significance $\leq 0,05$ maka dikatakan ada pengaruh bagian pelepah (sebagai perlakuan) terhadap parameter komponen kimia yang diukur sesuai dengan pendapat Hanafiah (2003) Apabila hasil analisis uji $F$ menunjukkan ada pengaruh maka dilakukan Uji Beda Nyata (BNT) taraf $1 \%$.

Sedangkan untuk penerapan modul dalam pembelajaran kimia dilakukan teknik analisis data menggunakan teknik analisis statistik (teknik analisis kuantitatif). Bila data berdistribusi normal maka digunakan uji statistic parametrik. Bila data tidak berdistribusi normal maka digunakan uji statistik non parametrik

\section{HASIL DAN PEMBAHASAN}

Hasil pengukuran komponen kimia pada pelepah sawit varietas tenera meliputi kadar zat ekstraktif yang larut dalam etanolbenzena, lignin, holoselulosa dan $\alpha$-selulosa.

\section{Kadar Zat Ekstraktif}

Rerata zat ekstraktif pelepah sawit varietas tenera pada bagian pangkal, tengah dan ujung disajikan pada Tabel 1. Tabel tersebut menunjukkan bahwa nilai rerata kadar zat ekstraktif pelepah sawit varietas tenera pada bagian pangkal, tengah dan ujung berturut - turut adalah 8,49\%, 7,87\% dan $6,74 \%$

Tabel 2. Nilai kadar zat ekstraktif rerata dari pelepah sawit varietas Tenera menurut bagiannya(\%)

Bagian Pelepah Kadar zat ekstraktif (\%)

\begin{tabular}{ll}
\hline Pangkal & $8.49^{\mathrm{a}}$ \\
Tengah & $7.87^{\mathrm{b}}$ \\
Ujung & $6.74^{\mathrm{c}}$ \\
\hline Rerata & 7.71 \\
\hline
\end{tabular}

Uji Anova mengindikasikan bahwa ditemukan pengaruh bagian pelepah terhadap kadar zat ekstraktif. Hasil uji lanjut dengan BNT pada Tabel 1, menunjukkan bahwa bagian pangkal dari pelepah sawit memiliki 
kadar zat ekstraktif yang signifikan lebih besar dari kadar zat ekstraktif bagian tengah dan ujung. Tabel tersebut juga menunjukkan bahwa rerata kadar zat ekstraktif bagian pangkal pelepah lebih besar daripada bagian tengah dan ujungnya begitu juga secara statistik kadar zat ekstraktif bagian pangkal lebih besar daripada bagian lainnya

Perbedaan kadar zat ekstraktif pada bagian pelepah sawit diduga semakin menuju ke pangkal, zat ekstraktif berupa lemak, lilin, resin, minyak dan tanin telah banyak dibentuk. Pada bagian pangkal diduga telah didominasi oleh sel-sel yang telah mengalami fase perubahan yang sempurna. Fase itu dimulai dari terbentuknya sel dengan satu dinding yang tipis (dinding primer). Setelah itu dinding mengalami penebalan dengan penambahan holoselulosa dan lignin yang disebut dengan penebalan sekunder. Tahapan selanjutnya adalah pengendapan zat ekstraktif yang umumnya terjadi pada bagian dalam rongga sel.

Pada kayu, sel-sel yang telah mengalami fase perubahan yang sempurna tersebut berada lebih banyak ditemukan pada bagian kayu teras dibandingkan pada kayu gubal. Haygreen dan Bowyer (1996) menegaskan bahwa kayu teras mempunyai konsentrasi zat ekstraktif yang tinggi daripada kayu gubal

Nilai rerata kadar zat ekstraktif yang terdapat pelepah sawit varietas tenera secara umum adalah $7,71 \%$. Jika nilai tersebut dibandingkan dengan klasifikasi komponen kimia kayu daun lebar Indonesia maka pelepah sawit varietas Tenera tergolong biomaterial yang berkadar ekstraktif tinggi, karena kadar zat ekstraktif > $4 \%$

Casey (1960) dalam Pari dan Saepulloh (2000) menyatakan bahwa besarnya kandungan ekstraktif pada biomaterial dapat mempengaruhi bahan kimia dalam pembuatan pulp dan kertas karena dapat bereaksi dengan alkali yang digunakan sebagai konsumsi alkalinya menjadi tinggi

\section{Kadar Lignin dan Hasil karakterisasi FTIR Lignin Pelepah Sawit Varietas Tenera}

Lignin merupakan polimer rantai panjang bercabang yang terdapat bersama sama dengan selulosa di dalam dinding sel kayu. Lignin berfungsi sebagai penyusun sel kayu. Lignin merupakan bagian terbesar dari selulosa dan merupakan senyawa aromatik.. Lignin akan mengikat serat selulosa yang kecil menjadi serat-serat panjang. Lignin tidak larut dalam larutan asam tetapi mudah larut dalam alkali encer dan mudah diserang oleh zat-zat oksida lainnya.

Lignin yang diperoleh dari hasil penelitian dikarakterisasi dengan spektrofotometer Inframerah (FTIR). Karakterisasi dengan FTIR bertujuan untuk mengetahui gugus fungsional khususnya lignin yang terdapat dalam serbuk pelepah sawit varietas Tenera .Spektrofotometri inframerah merupakan suatu metode yang mengamati interaksi molekul dengan radiasi elektromagnetik yang berada pada daerah pada bilangan gelombang $12.800 \mathrm{~cm}^{-1}$ hingga $10 \mathrm{~cm}^{-1}$. Karakterisasi dengan spekstroskopi IR yaitu suatu bahan diradiasi dengan cahaya infra merah, maka molekul pada bahan menjadi bergetar yang menimbulkan pita penyerapan pada ikatanikatan molekul gugus fungsi $\mathrm{C}-\mathrm{O}, \mathrm{O}-\mathrm{H}, \mathrm{C}-\mathrm{H}$ dan $\mathrm{N}-\mathrm{H}$

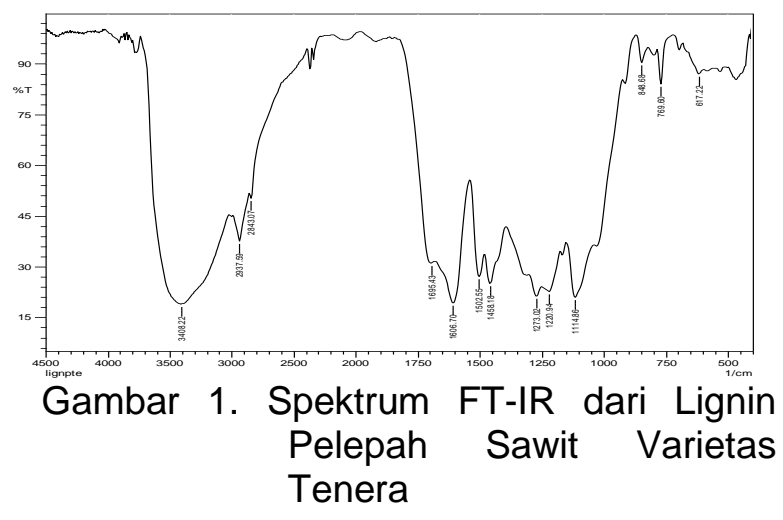

Analisis IR pada Gambar 1 menyatakan bahwa pada spektrum 3408,22 $\mathrm{cm}^{-1}$ menunjukkan adanya vibrasi ulur $\mathrm{O}-\mathrm{H}$, dan menunjukkan vibrasi ulur $\mathrm{C}-\mathrm{H}$ alifatik pada daerah 2937,59 $\mathrm{cm}$ dan $2843.07 \mathrm{~cm}^{-1}$. Daerah $1695.43 \mathrm{~cm}^{-1}$ menunjukkan $\mathrm{C}=\mathrm{O}$ nonkonjugasi, selanjutnya didukung puncak pada $1606.70 \mathrm{~cm}^{-1}$ dan $1502,55 \mathrm{~cm}^{-1}$ 
mengindikasikan adanya vibrasi cincin aromatik dan deformasi $\mathrm{C}-\mathrm{H}$ dikombinasikan dengan puncak pada $1458,18 \mathrm{~cm}^{-1}$ sangat umum untuk lignin meskipun intensitasnya berbeda-beda. Spektra daerah dibawah 1400 $\mathrm{cm}^{-1}$ sulit untuk dianalisis, karena terdapat spektrum yang kompleks dengan distribusi vibrasi yang bervariasi. Namun daerah ini mengandung vibrasi yang sangat spesifik untuk unit-unit monolignol dan karakteristik untuk lignin (Boeriu et al, 2004). Sampel lignin menunjukkan karakteristik unit guaiasil dengan vibrasi $\mathrm{CO}\left(1220,94 \mathrm{~cm}^{-1}\right.$, cincin guaiasil dan 1114,96 $\mathrm{cm}^{-1}$ menunjukkan adanya deformasi inplane $\mathrm{C}-\mathrm{H}$ ). Pada 848,68 $\mathrm{cm}^{-1}$ menunjukkan adanya out of-plane (OOP) aromatik yang merupakan ciri khas aromatik terkonjugasi.

Rerata kadar lignin pelepah sawit varietas tenera pada bagian pangkal, tengah dan ujung disajikan pada Tabel 2

Tabel 2. Nilai kadar lignin rerata dari pelepah sawit varietas Tenera menurut bagiannya $(\%)$

\begin{tabular}{lc}
\hline Bagian Pelepah & $\begin{array}{c}\text { Kadar Lignin Rerata } \\
(\%)\end{array}$ \\
\hline Pangkal & $20.7^{\mathrm{a}}$ \\
Tengah & $18.95^{\mathrm{ab}}$ \\
Ujung & $16.69^{\mathrm{c}}$ \\
\hline Rerata & 18.78 \\
\hline
\end{tabular}

Keterangan: nilai rata-rata yang diikuti dengan huruf yang sama berarti tidak berbeda nyata

Tabel 2 menunjukkan bahwa nilai rerata kadar lignin pelepah sawit varietas tenera pada bagian pangkal, tengah dan ujung berturut - turut adalah 20,7\%; 18,95\% dan $16,69 \%$. Kadar lignin pelepah sawit ini tidak berbeda jauh dengan kadar lignin kayu Mangium yang dilaporkan oleh Fetriana (2005) mengatakan bahwa rerata kadar lignin pada berbagai cabang kayu Mangium (Acacia mangium wild) adalah 19,30-23,72\%.

Hasil uji lanjut menunjukkan bahwa bagian pangkal dari pelepah sawit memiliki kadar lignin yang signifikan lebih besar dari bagian tengah dan ujungnya. Tabel tersebut juga menunjukkan bahwa rerata kadar lignin bagian pangkal pelepah lebih besar daripada bagian tengahnya namun secara statistik tidak berbeda nyata

Struktur penyusun bagian pelepah tersebut diduga menjadi penyebab adanya perbedaan antar bagian itu. Pada bagian pangkal didominasi oleh sel-sel yang telah mengalami penebalan sekunder sehingga dinding selnya cenderung lebih tebal seperti yang kemukakan oleh Tsoumis(1991) bahwa di dalam kayu, sebagai jenis biomaterial lain, lignin banyak terdapat dalam dinding primer dan lamella tengah. Akiyama, et.al (2005) kadar lignin tertinggi dijumpai dalam lamela tengah dan sedikit pada dinding sekunder,namun demikian kadar lignin yang terdapat dalam kayu bervariasi menurut jenis kayu, lokasi tempat tumbuh, bahkan dalam satu pohon yang sama

Apabila diklasifikasikan berdasarkan komponen kimia kayu daun lebar Indonesia sebagai bahan baku industri pulp maka kadar lignin pada masing-masing bagian pelepah sawit varietas tenera masuk dalam kategori sedang karena berada diantara 18\%-33\%.

Dalam industri pulp dan kertas, lignin adalah komponen kayu yang harus dihilangkan agar sel-sel kayu dapat terurai, maka dari itu kayu atau biomaterial berlignoselulosa yang mempunyai kadar lignin yang tinggi kurang baik untuk industri pulp dan kertas (Sutopo, 2005). Menurut Siagian dkk. (1999), bahwa dalam proses pembuatan pulp kimia, lignin harus dihilangkan, karena material dengan lignin tinggi akan membutukan bahan kimia yang lebih banyak.

\section{Kadar Holoselulosa dan Hasil Karakterisasi FTIR Holoselulosa Pelepah Sawit Varietas Tenera}

Kadar holoselulosa dalam kayu menyatakan jumlah dari senyawa karbohidrat atau polisakarida (jumlah selulosa dan hemiselulosa). Untuk mengetahui kadar holoselulosa digunakan natrium klorit yang berperan dalam reaksi delignifikasi. Selama reaksi delignifikasi bagian lignin kayu menjadi terlarut dengan reaksi subtitusi yang mengubah, merusak dan mengoksidasi lignin. 
Persentase kecil sisa lignin mungkin masih tetap tertinggal dalam holoselulosa.

Hasil karakterisasi dengan FTIR pada sampel holoselulosa pelepah sawit varietas tenera di tampilkan pada Gambar 2 dibawah ini

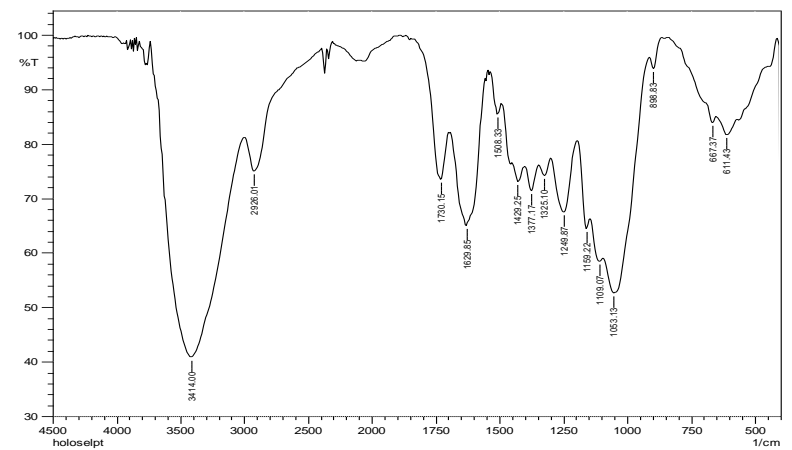

Gambar 2. Spektrum FT-IR dari Holoselulosa Pelepah Sawit Varietas Tenera

Berdasarkan Gambar 2 diatas menunjukkan bahwa pada bilangan gelombang $3414 \mathrm{~cm}^{-1}$ dan 2926,01 $\mathrm{cm}^{-1}$ merupakan serapan gugus fungsi $\mathrm{O}-\mathrm{H}$ dan $\mathrm{C}-$ H. Pada 1730,15 $\mathrm{cm}^{-1}$ dan $1377,17 \mathrm{~cm}^{-1}$ diduga serapan $\mathrm{C}-\mathrm{H}$ dari hemiselulosa. Hemiselulosa memiliki gugus fungsi yang hampir sama dengan selulosa, dan dibedakan dengan serapan IR asam uronat $\left(1593 \mathrm{~cm}^{-1}\right)$ dan xilan $\left(1150 \mathrm{~cm}^{-1}\right)$ pada hemiselulosa (Fang et al. 2000). Pada $1730.15 \mathrm{~cm}^{-1}$ juga merupakan serapan gugus karbonil $(\mathrm{C}=\mathrm{O})$. Gugus -O- yang merangkai $-\mathrm{CH}_{2^{-}}$pada selulosa yang merupakan polimer glukosa terlihat pada bilangan gelombang 1300-1400 $\mathrm{cm}^{-1}$ yaitu pada $1377,17 \mathrm{~cm}^{-1}$. Sedangkan pada $1629,85 \mathrm{~cm}^{-1}$ dan $1508,33 \mathrm{~cm}^{-1}$ diduga merupakan serapan $\mathrm{C}=\mathrm{C}$ aromatis atau serapan IR dari asam uronat. Untuk serapan C-O ulur ditunjukkan pada bilangan gelombang 1249,87 $\mathrm{cm}^{-1}$. Pada bilangan gelombang 1159,22 $\mathrm{cm}^{-1}$ diduga serapan Xilan dari hemiselulosa dan serapan C-C cincin piranosa pada bilangan gelombang $1109,07 \mathrm{~cm}^{-1}$ dan $1053,13 \mathrm{~cm}^{-1}$ serta ikatan glikosida antar glukosa ditunjukkan pada bilangan gelombang $898,83 \mathrm{~cm}^{-1}$.

Kadar holoselulosa rerata dari pelepah sawit varietas tenera pada bagian pangkal, tengah dan ujung disajikan pada Tabel 3. Tabel tersebut menunjukkan bahwa nilai rerata kadar holoselulosa pelepah sawit varietas tenera pada bagian pangkal, tengah dan ujung berturut - turut adalah $81,57 \%$; $80,33 \%$ dan $79,24 \%$.

Tabel 3 Nilai kadar holoselulosa rerata dari pelepah sawit varietas Tenera menurut bagiannya(\%)

\begin{tabular}{lc}
\hline Bagian Pelepah & $\begin{array}{c}\text { Kadar Holoselulosa } \\
\text { Rerata (\%) }\end{array}$ \\
\hline Pangkal & $81.57^{\mathrm{a}}$ \\
Tengah & $80.33^{\mathrm{b}}$ \\
Ujung & $79.24^{\mathrm{c}}$ \\
\hline Rerata & 80.38 \\
\hline \multicolumn{1}{c}{ Hasil uji lanjut menunjukkan bahwa }
\end{tabular}
bagian pangkal dari pelepah sawit memiliki kadar holoselulosa yang signifikan lebih besar dari kadar holoselulosa bagian tengah dan ujung.

Perbedaan kadar holoselulosa pada pelepah sawit varietas tenera diduga karena bagian pangkal mempunyai dinding sekunder yang lebih tebal dibandingkan bagian tengah dan ujung. Holoselulosa banyak terdapat pada dinding sel seperti yang dikemukakan oleh Fengel dan Wegener (1995) bahwa di dalam kayu senyawa polisakarida banyak terdapat pada bagian dinding sel sekunder yang berfungsi untuk memperkuat struktur yang di dalamnya mengandung senyawa glukomanan, arabinosa, galaktosa, glukoronoxylan, glukosa, asam uronat, dan xylosa.

Dari hasil penelitian ini diduga bahwa kadar holoselulosa pelepah sawit varietas tenera pada bagian pangkal, tengah dan ujung layak untuk dijadikan bahan baku pulp karena kadar holoselulosanya diatas 65\%. Dugaan tersebut didasarkan pada pernyataan FAO dalam Pari dan Saepuloh (2000) bahwa kayu dengan kadar holoselulosa yang lebih dari $65 \%$ akan dapat dijadikan sebagai bahan baku pulp dan kertas

Pada pembuatan pulp dan kertas diperlukan kadar holoselulosa yang tinggi karena memberikan kekuatan yang baik terhadap kertas yang dihasilkan (Siagian dkk,,2003). Razal (1999) dalam Yahya dan Meshitsuka (2004) menambahkan bahwa 
kandungan holoselulosa yang tinggi sangat diperlukan oleh industri pulp karena berhubungan dengan tingginya rendemen pulp yang dihasilkan. Kayu dengan kadar holoselulosa yang tinggi akan dapat digiling.

\section{Kadar a-selulosa dan Hasil Karakterisasi FTIR a-selulosa Pelepah Sawit Varietas Tenera}

a-selulosa adalah selulosa berantai panjang, tidak larut dalam larutan $\mathrm{NaOH}$ $17,5 \%$ atau larutan basa kuat dengan derajat polimerisasi 600-1500. Tarmansya (2007) menyatakan bahwa a-selulosa digunakan untuk menduga atau menentukan tingkat kemurnian selulosa dan merupakan kualitas selulosa yang paling tinggi.

Spektroskopi FTIR menjadi metode yang sederhana dan cepat untuk menentukan jenis senyawa berdasarkan vibrasi khasnya (Silverstein et al. 2005). Serapan pada bilangan gelombang $3340 \mathrm{~cm}^{-1}$ (ulur $\mathrm{O}-\mathrm{H}$ ), $2899 \mathrm{~cm}^{-1}$ (ulur C-H), 1639 (tekuk O-H), 1427 $\mathrm{cm}^{-1}$ (tekuk C-H), $1100-1000 \mathrm{~cm}^{-1}$ (ulur C-OC dan C-O), dan $896 \mathrm{~cm}^{-1}$ (ikatan B-glikosida) yang khas untuk selulosa (Abidi et al. 2013)

Hasil karakterisasi dengan FTIR pada sampel a-selulosa pelepah sawit varietas tenera di tampilkan pada Gambar 3 dibawah ini

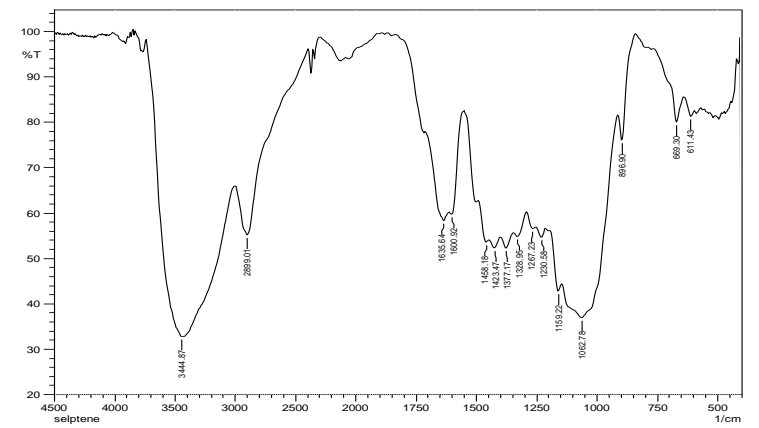

Gambar 3. Spektrum FT-IR a-selulosa dari Pelepah Sawit Varietas Tenera

Berdasarkan Gambar 3 diatas menunjukan bahwa pada bilangan gelombang $3444,87 \mathrm{~cm}^{-1}$ dan $2889,01 \mathrm{~cm}^{-1}$ merupakan serapan gugus $\mathrm{O}-\mathrm{H}$ dan $\mathrm{C}-\mathrm{H}$, pada bilangan gelombang $1635.64 \mathrm{~cm}^{-1}$ dan $1600,92 \mathrm{~cm}^{-1}$ merupakan serapan dari $\mathrm{C}=\mathrm{C}$ aromatis, sedangkan pada bilangan gelombang
$1267,23 \mathrm{~cm}^{-1}$ dan $1230,58 \mathrm{~cm}^{-1}$ menunjukkan serapan C-O. Cincin $\mathrm{C}=\mathrm{C}$ piranosa ditunjukkan pada bilangan gelombang $1159,22 \mathrm{~cm}^{-1}$ dan 1062,78 $\mathrm{cm}^{-1}$ Pada bilangan gelombang 896,90 menunjukkan ikatan glikosida antar glukosa.

Kadar a-selulosa rerata dari pelepah sawit varietas tenera pada bagian pangkal, tengah dan ujung disajikan pada Tabel 4, Rerata kadar a-selulosa pelepah sawit varietas tenera pada bagian pangkal, tengah dan ujung berturut - turut adalah 44,7\%; $43,56 \%$ dan $43,26 \%$.

Tabel 4. Nilai kadar $\alpha$-selulosa rerata dari pelepah sawit varietas Tenera menurut bagiannya(\%)

\begin{tabular}{lc}
\hline $\begin{array}{c}\text { Bagian } \\
\text { Pelepah }\end{array}$ & $\begin{array}{c}\text { Kadar a-selulosa Rerata } \\
(\%)\end{array}$ \\
\hline Pangkal & $44.7^{\mathrm{a}}$ \\
Tengah & $43.56^{\mathrm{b}}$ \\
Ujung & $43.26^{\mathrm{bc}}$ \\
\hline Rerata & 43.84 \\
\hline
\end{tabular}

Keterangan: Nilai rata-rata yang diikuti dengan huruf yang sama berarti tidak berbeda nyata

Hasil uji lanjut menunjukkan bahwa bagian pangkal dari pelepah sawit memiliki kadar $\alpha$-selulosa yang signifikan lebih besar dari kadar a-selulosa bagian tengah dan ujung

Perbedaan kadar a-selulosa pada pelepah sawit ini diduga terkait dengan variasi komposisi dinding sel kayu dalam tiap pohon karenakan selulosa merupakan pembentuk komponen serat dari dinding sel tumbuhan. Menurut Syafii dan Siregar (2006), kandungan a-selulosa dalam kayu dapat digunakan untuk memperkirakan besarnya rendemen pulp yang dihasilkan dalam proses pulping, dimana semakin besar kadar $\alpha$-selulosa dalam kayu maka semakin besar pula rendemen pulp yang dihasilkan

Apabila dibandingkan dengan klasifikasi komponen kimia kayu Indonesia (Tabel4) bahwa ketiga bagian dari pelepah sawit varietas tenera tersebut memiliki kadar $\alpha$ selulosa yang sedang yaitu 40 - 45\%. 
Kandungan a-selulosa pelepah sawit tersebut cukup tinggi dan memenuhi persyaratan untuk bahan baku pulp dan kertas. Kandungan selulosa yang tinggi akan menghasilkan rendemen pulp yang tinggi juga.

\section{Penerapan Modul dalam Pembelajaran Kimia}

Dua kali test yang dilakukan dalam penelitian ini yaitu pretest dan post test. Tes ini diberikan untuk mengetahui seberapa besar pengaruh pemberian modul terhadap hasil belajar pada aspek kognitif dari kelas tersebut. Dari hasil pretest dan post test yang diperoleh terlihat bahwa nilai rata-rata pretest adalah 56,32 dan rata-rata post test 85,12 (Gambar 4 )

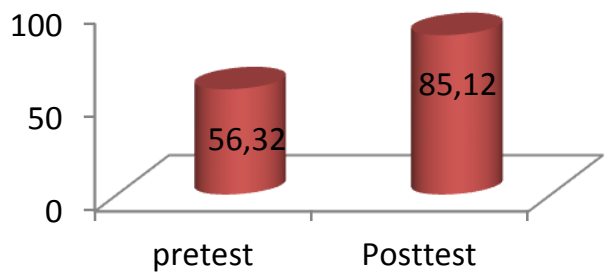

Gambar 4. Rata-rata Hasil pretest dan Post test

Dari Gambar 4. menunjukkan bahwa nilai posttest yang dicapai oleh siswa lebih tinggi dibandingkan nilai pretest. Kenaikan nilai post test setelah pembelajaran menggunakan modul makromolekul pelepah sawit varietas tenera diduga karena isi modul bersifat interaktif yang membangun pola pikir siswa untuk mengembangkan keiingintahuan terhadap materi yang dipelajari. Pembelajaran menggunakan modul ini disertai dengan metode diskusi kelompok, membuat siswa lebih aktif sehingga terjadi komunikasi dua arah antara guru dengan siswa dan sesama siswa baik dalam kelompoknya maupun secara klasikal.

Berdasarkan hasil uji normalitas Kolmogorov-Smirnov digunakan hasil pretes dan posttest untuk kelas eksperiment ini, jika signifikansi > 0,05 maka populasi data berdistribusi normal. Dari hasil uji normalitas Kolmogorov-Smirnov bahwa signifikansi pretest sebesar 0,287. Signifikansi hasil postes sebesar 0,244. Karena signifikansi untuk seluruh variabel lebih besar dari 0,05, maka dapat disimpulkan bahwa hasil pretest dan postest berdistribusi normal

Berdasarkan hasil analisis dari angket respon siswa terhadap modul diperoleh skor rata-rata untuk aspek ketertarikan adalah 23,64, untuk aspek materi adalah 24,48 dan 14,48 untuk aspek bahasa dalam modul yang digunakan dalam pembelajaran kimia. Dari hasil analisis tersebut diketahui bahwa ketiga komponen penilaian termasuk dalam kategori sangat baik menurut penilaian siswa.

Dari data tersebut di atas menunjukkan bahwa siswa memberikan respon positif setelah penggunaan modul dalam pembelajaran. Siswa lebih memahami ketika mempelajari materi makromolekul karena tampilan modul yang menarik dan sajian materi dalam modul yang menggunakan inkuiri proses dimana isi modul tidak langsung pada materi inti tetapi diberikan ilustrasi , gambar dan pertanyaan terbuka yang mendorong rasa ingin tahu dan membuat siswa dapat menemukan konsep. selain itu juga modul dilengkapi gambar dan bahasa yang sederhana sehingga mudah dipahami oleh siswa

\section{KESIMPULAN}

1. Berdasarkan analisis variannya, perbedaan bagian pelepah (pangkal, tengah dan ujung) dari pelepah sawit varietas tenera berpengaruh nyata terhadap kerapatan dan komponen kimianya dengan kerapatan menurut bagiannya dari pangkal, tengah dan ujung adalah $0,42 \mathrm{~g} / \mathrm{cm}^{3}, 0,38 \mathrm{~g} / \mathrm{cm}^{3}$, dan 0,36 $\mathrm{g} / \mathrm{cm}^{3}$ sedangkan kadar komponen kimia menurut bagiannya dari pangkal, tengah, ujung berturut-turut dengan rerata untuk kadar zat ekstraktif 8,49\%, 7,87\%, 6,74\%, Lignin $\quad 20,7 \%, \quad 18,95 \%, \quad 16,69 \%$. Holoselulosa 81,57\%, 80,33\%, 79,24\% dan $\alpha$ - selulosa $44,57 \%, 43,56 \%, 43,26 \%$

2. Berdasarkan klasifikasi komponen kimia kayu daun lebar Indonesia, pelepah sawit varietas tenera pada ketiga posisinya baik dijadikan sebagai bahan baku pulp karena 
memiliki kadar lignin yang sedang, kadar Holoselulosa yang tinggi dan kadar $\alpha$ selulosa yang sedang

3. Pembelajaran Kimia pada kelompok Sains (ICHO) di SMA Negeri 2 Kota Bengkulu dengan menggunakan modul memberikan peningkatan yang signifikan terhadap hasil belajar siswa, dimana terdapat perbedaan secara signifikan antara nilai rata-rata posttest $(85,12)$ dengan rata-rata nilai pretest $(56,32)$ dan KKM $(75)$

\section{DAFTAR PUSTAKA}

Abidi N, Cabrales L, Haigler CH. 2013. Changes in the cell wall and cellulose content of developing cotton fiber investigated by FTIR spectroscopy.Carbohydr Polym.xxx:8-16.

Achmadi, S.S. 1990. Kimia Kayu. Departemen Pendidikan dan Kebudayaan Direktorat Jenderal Pendidikan Tinggi Pusat Antar Universitas IImu Hayat. Institut Pertanian Bogor.

Akiyama, T., Goto, H., Nawawi, D. S., Syafii, W.,Matsumoto, Y., \& Meshitsuka, G. (2005). Erythro/threo Ratio of B-O-4, Structures as an important structural characteristic of lignin. Part 4: Variation in the erythro/threo ratio in softwood and hardwood lignis and its relation to syringyl/guaiacyl ratio. Holzforschung, $59,276-281$

Ambarita, Y.P., I. Pandang, Maulina S. 2015. Pembuatan Asam Oksalat dari Pelepah Sawit (Elaeis guineensis) melalui Reaksi Oksidasi Asam Nitrat. Jurnal Teknik Kimia. Universitas Sumatera Utara. Vol. 4 No 4

Boeriu. et al. 2004. "Characterization of structuredependent functional properties of lignin withinfrared spectroscopy". Industrial Crops and Products 20:205-218

Bowyer, J., Shmulsky, R. \& Haygreen, J.G. 2003. Forest Products and Wood Science-an Introduction. Fourth edition. lowa: lowa State Press.
Cahya. 2011. Strategi PT. Kertas Nusantara. Institut Pertanian Bogor

Fang JM, Sun RC, Tomkinson J. 2000. Isolation and characterization of hemicellulose and cellulose from rye straw by alkaline peroxide extraction Cellulose. 7:87-107

Fengel, D \& Wegener, G. 1995. Kayu kimia Ultrastruktur dan Reaksi - reaksi. Penerjemah H. Sastrohamdjojo. Gadjah Mada University Press. Yogyakarta

Gusmailina dan D. Setiawan, 1996. Analisis Kimia Kayu Kasievera (Cinnamomumj burmanii Ness ex.BL) dan Prospek Pemanfaatannya. Info Hasil Hutan. Badan Penelitian dan Pengembangan Kehutanan. Pusat Penelitian dan Pengembangan Hasil Hutan dan Sosial Ekonomi Kehutanan. Bogor. Vol. III No1

Hanafiah, K.A. 2003. Rancangan Percobaan Teori dan Aplikasi. Edisi ketiga. PT. Raja Grafindo Persada. Jakarta.

Haygreen JG dan Bowyer JL. 1996. Hasil Hutan dan IImu Kayu. Yogyakarta (ID): Terjemahan Gadjah Mada University.

KemenPerin. 2011. Kapasitas Produk Pulp Nasional dan Besarnya Peningkatan Produksi. Kementerian Perindustrian Republik Indonesia. Jakarta

Pari, G dan Saepuloh.2000. Analisis Komponen Kayu Mangium Pada Beberapa Macam Umur Asal Riau. Buletin Penelitian Hasil Hutan. Vol 17. No. 3. Hal $140-148$

Pasaribu,R.A. 1990. Sifat Kimia Kayu. Bogor: Balai Penelitian Hasil Hutan

Siagian, R.M., . Roliadi., S. Suprapti., dan s.Komaryati. 2003. Studi Peranan Fungi Pelapuk Putih dalam Proses Biodelignifikasi Kayu Sengon (Paraserinthes falcataria L.Nielson). Jurnal Ilmu dan Teknologi Kayu Tropis Vol. 1. No. 1 
Silverstein RM, Bassler GC, Morrill TC. 2005. Spectrometric Identification of Organic Compound. Ed ke-7. New York (US): J Wiley

Sugiyono.2008.Metode Penelitian Pendidikan. Bandung: Alfabeta

Sutopo, R. S. (2005). Karakteristik Industri Pulp dan Kertas. Bandung: Balai Besar Pulp dan Kertas

Tappi Test Methods. Penentuan Kadar Ekstraktif T 204, Penentuan Kadar Holoselulosa T 9, Penentuan Lignin T 222, Penentua Kadar $\alpha$ - selulosa T 203. TAPPI Press. Atlanta.

Tarmansya, U.S. 2008. Pemanfaatan Serat Rami Untuk Pembuatan Selulosa. Buletin Balitbang Deptan. Litbang Pertanian Indonesia
Wardani, L. 2015. Pemanfaatan Pelepah Sawit Sebagai Bahan Baku Papan Zephyr. [Desertasi]. Bogor: Institut Pertanian Bogor

Yahya,R.2013. Comparison of Density and Chemical Components of Oil Palm Empty Fruits Bunches Between Varieties Dura and Tenera. Makalah dipresentasikan pada The $3^{\text {th }}$ International Symposium for Sustanaible Humanosphere, Bengkulu 17 - 18 September 2013.

Zulfansyah, Fermi M.I., Amraini S.Z., Rionaldo H., Utami M.S. 2011. Pengaruh Kondisi Proses Terhadap Yield dan Kadar Lignin Pulp dari Pelepah Sawit dengan Proses Asam Formiat. Jurnal Rekayasa Kimia dan Lingkungan vol 9. Hal 12 19 